\title{
"PROBASHI" IN ITALY. NEW DESTINATIONS: TRENDS, ORIGINS AND PROFILES OF BANGLADESHI MIGRANTS IN PADOVA AND CADONEGHE
}

\author{
Mohammad MORAD', Jure GOMBAČ"
}

COBISS 1.01

\section{ABSTRACT \\ "Probashi"1 in Italy. New Destinations: Trends, Origins and Profiles \\ of Bangladeshi Migrants in Padova and Cadoneghe}

Most of the studies on Bangladeshi migration to Italy have been conducted in cities and towns that already have a relatively long tradition of hosting Bangladeshi communities, such as Rome, Vicenza and Venice. This article focuses on two recent local contexts of Bangladeshi migration to Italy: Padova and Cadoneghe in the Veneto region. The study attempts to answer the following research questions: What are the trends, channels and motivations behind Bangladeshi migration to Padova and Cadoneghe, from which Bangladeshi regions do the migrants originate and what are their cultural, socio-demographic and economic profiles?

KEY WORDS: Bangladeshi migrants, migration trends, motivations for migration, migrant profiles, migration to Italy

\section{IZVLEČEK}

„Probashiji « v Italiji. Nove destinacije: Trendi, izvori in profili bangladeških migrantov v Padovi in Cadonegheju

Avtorja v članku ugotavljata, da se večina znanih objavljenih raziskav o migracijah iz Bangladeša $v$ Italijo osredotoča na mesta z dolgoletnimi izkušnjami z bangladeškimi skupnostmi, na primer Rim, Vicenzo in Benetke. Za svojo raziskavo sta zato izbrala dve lokalni skupnosti, kamor se bangladeški migranti priseljujejo v zadnjem času, in sicer mesti Padova in Cadoneghe v Benečiji. S pomočjo podatkov, pridobljenih z vprašalniki in s številnimi intervjuji, odgovarjata na zastavljena vprašanja o trendih, kanalih in motivacijah, ki bangladeške migrante v zadnjem času usmerjajo v Padovo in Cadoneghe, zanimajo pa ju tudi izvor migrantov in njihov kulturni, sociodemografski in ekonomski profil.

KLJUČNE BESEDE: migranti iz Bangladeša, migracijski trendi, motivacije za migracijo, migracija v Italijo, profili migrantov

\footnotetext{
PhD candidate, School of Social Sciences: Interactions, Communication, Cultural Constructions, Department of FISPPA, Section of Sociology, University of Padova, Via M. Cesarotti 10/12, Italy-35123 Padova; mohammad.morad@studenti.unipd.it

\| PhD in Sociology, Associate professor, University of Nova Gorica, Senior Research Fellow, Slovenian Migration Institute, SRC SASA, Novi trg 2, SI-1000 Ljubljana; jgombac@zrc- sazu.si

1 Probashi is the Bangladeshi term for expatriate.

2 Probashi je bangladeška beseda za izseljence.
} 


\section{INTRODUCTION}

Approximately 0.6 to 0.7 million Bangladeshis leave their country of origin and migrate to various destinations across the globe every year (ILO 2014). International migration has been growing rapidly since 1976, when the Bangladesh government started promoting international migration as a part of their overall development plan by establishing a government agency called the Bureau of Manpower, Employment and Training (BMET) (Rahman 2012). It has been estimated that about 10.5 million Bangladeshi migrants were working in 157 countries between 1976 and 2016 (BMET 2016). Among them, as Siddiqui (2004) estimated, almost 1.2 million reside as citizens, residents or holders of other valid documents in several countries of Europe and North America, and also in Australia. An ever-growing Bangladeshi diaspora is spreading transnational ties across the world and contributing to the development of their homeland in several ways.

In Europe, the UK was traditionally and still is recognized as a top destination for Bangladeshi migrants (Morad et al. 2014). Italy however has recently emerged as one of their major destinations (Knights 1996a, 1996b; Zeitlyn 2006; Morad, Gombač 2015). This is also a consequence of the Mediterranean route, which leads through Italy and other Mediterranean countries, being one of the most important routes to the European Union. The statistics regarding Italy tell an interesting story: in 1995 there were 5,541 Bangladeshis officially present in Italy (Knights, King 1998), but recent data from the Italian government statistics website (for 31 December 2016) show that Bangladeshis are already the 5th-largest non-European community in Italy, with 122,428 members (Istat 2016a). Italy also hosts many undocumented Bangladeshi migrants. It was estimated that there were about 74,000 living in Italy in 2009 (Rahman, Kabir 2012).

Most of the studies have been conducted in large cities that have a relatively long tradition of hosting Bangladeshi communities, such as Rome, Vicenza, and Venice. In his seminal study, Knights (1996b: 105) argued that the majority of Bangladeshis in Italy lived in Rome. However, the data show that in recent years their presence can also be documented and observed in southern, central, north-eastern and north-western Italy (Della Puppa 2014, 2015; Priori 2012; Quattrocchi et al. 2003). As this is a relatively new development it comes as no surprise that there was little or no research being done about Bangladeshi communities in smaller Italian cities and towns (Della Puppa, Gelati 2015). Therefore, this article focuses on two recent local contexts of Bangladeshi migration, namely Padova and Cadoneghe in the Veneto region. The following research questions were posed: what are the trends, channels and motivations behind Bangladeshi migration to Padova and Cadoneghe, from which regions of Bangladesh do the migrants originate and what are their cultural, socio-demographic and economic profiles?

This paper begins by outlining the data and the methodology. It then goes on to a brief overview of the context of the study. The subsequent sections present the empirical findings regarding the migration history, migration channels, motivations, 
regional origin in Bangladesh and their cultural, socio-demographic and economic profiles. The final section presents the concluding remarks.

\section{DATA AND METHODS}

The study was based on a mixed-method approach in which qualitative and quantitative methods were combined. With the help of snowball sampling, a sample of 100 Bangladeshi migrants from Padova and Cadoneghe was identified and a survey was conducted between December 2012 and March 2013. Among these respondents, more than half (56 migrants) were found to be permanent residence holders, $26 \mathrm{mi}$ grants had temporary residence, nine had Italian citizenship and nine were undocumented. The survey covered a wide range of issues concerning their migration experiences: year of arrival, migration trajectory, motivation for migrating, geographical origin in Bangladesh, socio-economic background, age, gender, religion, education, marital status, profession and income. Certain survey topics were further explored using qualitative methods in order to obtain a deeper insight. In-depth interviews were conducted with 12 migrants and five of their non-migrant family members in Bangladesh. Participant observation in public places with a high concentration of migrants such as parks, restaurants, bars, mosques, ethnic shops and cultural centres also served as additional sources of data.

\section{RESEARCH CONTEXT}

Padova and Cadoneghe are two municipalities in the Province of Padova, which is situated in northern Italy and is a part of the Veneto region. Because of its industrial development and economic growth, the Veneto region has been one of the most important destinations for migrants since the 1970s (Luongo 2011). These days the region has the highest percentage of foreigners in Italy. In 2016 there were 5,047,028 migrants living in Italy and nearly 10 percent of them were living in Veneto (Istat 2016a).

In 2016, there were nearly 4.9 million inhabitants living in Veneto, of whom almost 1.2 million were migrants (Istat 2016). Bangladeshis were the third-largest non-European migrant community in the region, numbering 15,852, after Moroccans and Chinese. Among the seven provinces of Veneto - Belluno, Padova, Rovigo, Treviso, Verona and Vicenza - Padova is the second most populous $(936,274$ inhabitants) and there were 93,268 migrants living there in 2016 , of whom 1,655 originated from Bangladesh.

Seventy-two percent of all Bangladeshis residing in this province live in the municipality of Padova, while 7 percent live in Cadoneghe. They represent 3.7 percent of the total migrant population in the municipality of Padova and 62 percent of total migrants in Cadoneghe (Istat 2016). 


\section{HISTORY AND TRENDS OF MIGRATION TO ITALY}

Bangladeshi migration to Italy has a relatively short history. While migration to the UK, the main destination for Bangladeshis in Europe, has its roots in British Colonialism (Siddiqui 2003, 2004; Gardner 1995, 2010; Morad et al. 2014) migration to Italy has been described as a symptom of the new globalization of migration processes, since little or no geographical closeness, colonial affiliation, religious, linguistic or other relationships exist between these two countries (Knights 1996b; Knights, King 1998). But as some of the other European countries - such as Germany, France and the Netherlands - have tightened their migration policies, reducing the opportunity for legal entry and residence, Italy's flexible migration policy as well as periodic regularization procedures have encouraged Bangladeshis to move to Italy as they saw the prospect of becoming permanent residents of the EU (Della Puppa 2013, 2014; Priori 2012; Knights 1996a, 1996b). In fact, Italy is still perceived as a country with a relatively inclusive labour market and "instrumentally lax" migration policies (Della Puppa 2014). In this regard, the amnesties that allowed irregular migrants to regularize their status - especially the ones in 1986, 1990 and 1998 - had the effect of accelerating Bangladeshi migration to Italy (Knights 1996b; Knights, King 1998).

As research has shown, Bangladeshi migrants started to arrive in Italy in the late 1980s, but the numbers increased from the early 1990s on (Knights, King 1998; Zeitlyn 2006, 2007). Once Bangladeshi migrants successfully obtained their residence permits and settled in major Italian cities such as Rome and Milan, some of them started to move to other urban centres. The industrial development in the northern part of the country in particular stimulated this "internal" migration towards better social conditions, employment and expected income (Zeitlyn 2006, 2007; Della Puppa 2013). Several "Bangla towns" have been established in different areas of the country (Della Puppa 2015).

The establishment of the Bangladeshi community in Padova began in the mid1980s. Interviews indicated that three Bangladeshi migrants who arrived from Rome played the pioneering role in establishing the Bangladeshi community. As mentioned by one of them: "In 1986 three Bangladeshis, myself from Comilla, another two from Sylhet and Faridpur, came here from Rome in search of work. Later, we brought our relatives, family, and friends from Bangladesh. We grew here day by day and now we are a big community" (Interview 6, 7. 1. 2013).

The numbers have been growing since 1998, the largest number of people migrating there in the 2000s.' Most of the Bangladeshi migrants who came to Italy in the 1980s and even the 1990s came from other parts of Europe by taking various statuses such as refugees, students, short-term trainees, and some as undocumented migrants. (Knights 1996a, 1996b; Della Puppa 2014; Priori 2012). However in the case

1 Overall, the average period of stay in Padova was 12.6 years, with the highest being 28 years and the lowest 1 year. 
of Padova and Cadoneghe, they also came from the Middle East: 13 respondents came from Saudi Arabia and the United Arab Emirates.

\section{MIGRATION CHANNELS}

It comes as no surprise that Bangladeshi migrants have used both legal and irregular migration channels in order to reach Italy. Regular channels were used by 66 respondents: 21 of them migrated on work visas and others on short-term permits such as seasonal labour visas, tourist visas, Schengen visas from other EU countries and training visas, and then overstayed the visa expiration date because they had the opportunity to work in the shadow economy and hoped to be able to regularize their status via the periodic legalization of irregular migrants in Italy. In addition, family reunification visas, which were used by 17 respondents, have also become a popular channel since 1998.

As Italy is ringed by a long coastline, 'ease of entry' has potentiated irregular migratory flows (King, Rybaczuk 1993; Delicato 2004). It is also close to sending and transit regions such as North Africa and Albania. Bangladeshi migration to Italy during the 1980s and 1990s was mostly irregular (Knights 1996b; Knights, King 1998). The results of the survey showed that the majority of the Bangladeshis who entered Italy before 2000 (26 out of 37 respondents) were irregular migrants, especially those that entered Italy in the period between 1986 and 1997. After this period the flow of undocumented migrants diminished but did not disappear: 44 respondents followed irregular channels but did not consider their entry as irregular. They rather stated that they entered Italy by using "Tarzan" visas. ${ }^{2}$ Qualitative interviews also revealed the fact that, similar to the case of Rome (Knights, King 1998), respondents in Padova and Cadoneghe usually used more than one irregular route, a combination of 'air and land' or 'air and sea', or 'air, sea, and land' routes.

With regard to the air and land route, the study shows that Eastern Europe was an important area for this transit migration. The in-depth interviews revealed that a number of Bangladeshis first travelled to Eastern European countries on a tourist visa for one or three weeks and later came to Italy as undocumented migrants. As one of the Bangladeshis stated: "I first came to Hungary from Dubai with a tourist visa for three weeks and from there I came to Italy in 1992 by road using Slovenia" (interview 5, 6. 1. 2013). In a similar way, another respondent said: "I worked in Dubai for two years. Later I obtained a tourist visa for Austria and I entered Italy in 1994" (interview 11, 26. 1. 2013).

Other Bangladeshis in Padova and Cadoneghe who used the Eastern European route mentioned Romania, Hungary, Austria, and Bulgaria as their transit countries.

2 Not an official visa, it was called a Tarzan visa by their recruiting agents. They had to travel through jungles and hills in order to reach Italy. 
More specifically, the entry points were on the Italian borders with France, Switzerland, Austria and Slovenia. As Padova is very close to Slovene-Italian border, most of them entered Italy through Trieste and Gorizia. Nevertheless, several Bangladeshis mentioned that this route has become less and less used in the recent years as the air and sea routes to Italy have become more popular. In this regard, the interviews confirm that Bangladeshis have mainly managed to obtain tourist visas for Middle Eastern countries and then move to North African countries, especially Libya. ${ }^{3}$ They reach Italy by crossing the Sicilian Channel on the Mediterranean Sea along with other migrants from Africa. For instance, one of the respondents stated: "At first, I came to Libya from Bangladesh in 1992 on a tourist visa. I was there one week, later we took a ship, we were 25 in the boat, and arrived in Sicily ..." (interview 4, 5. 2013). According to our survey data, of the Bangladeshis who moved to Italy illegally since 2000 (24 migrants out of 100), a major portion (15 migrants) used the Central Mediterranean route via Libya. In this case, some of the respondents also mentioned that they used Turkey and Malta as their transit points for entering Italy via the Mediterranean.

Some irregular migrants looked for several possible routes during their transit to Italy, a combination of air, land, and sea routes. In this regard, Turkey, Russia, Greece and Malta were the most frequently mentioned transit countries. One of the Bangladeshi migrants who now holds Italian citizenship described his experience as follows:

In 1992 I started my journey from Bangladesh with a Russian tourist visa. I had been there for a long nine months while I was always searching for a way to reach Italy. Later I came to Romania and I was there about one year. Then I came to Turkey illegally but I was arrested by the police and sent to Turkish jail for two months. After that, I was in a refugee camp for four months from where I ran away one day and entered Greece by boat. But I was arrested in Athens and sent to jail. When I was released after three months, I entered Italy by using several Balkan countries. (Interview 10, 14. 1. 2013)

\section{MOTIVATION FOR MIGRATING}

Europe has traditionally been perceived as a favourable destination for Bangladeshi migrants compared to the Middle-Eastern and South-East Asian industrial countries, ${ }^{4}$ particularly for those who had the aspiration of settling abroad as long-term migrants. Siddiqui (2003) found in her research that Bangladeshi long-term migrants

3 Bangladeshi migrants working in Middle Eastern countries with short-term contracts also used this route to reach Italy.

4 In the case of short-term migration, the main destinations are Middle-Eastern countries such as Saudi Arabia, the United Arab Emirates, Kuwait, Bahrain, Qatar, Oman, and some other Gulf countries. In addition, South-East Asian countries such as Malaysia, Singapore, Hong Kong, Republic of Korea, Brunei, Dar es Salaam and other places also emerged as popular destinations for short-term migration of Bangladeshi people (BMET 2016). 
were pulled towards Europe and North America because of access to specialized jobs, better health care systems, wider opportunities for 'self-actualization' and better educational opportunities for their children. At the same time, they were pushed from their country because of political turmoil, violence, insecurity and corruption in Bangladesh.

These findings are highly concordant with the findings of the survey in Padova and Cadoneghe. The majority of the participants (68 out of 100 migrants) highlighted the already mentioned pull factors such as having better employment and income in Italy, being reunited with their families, better human rights situation etc. In contrast, 34 migrants pointed to unemployment and lack of job prospects, poor economic conditions and political uncertainty as push factors in Bangladesh.

With the help of qualitative interviews, we tried to further explore the details of these aspects. The findings indicated that the respondents' migration decisions were influenced by several factors: First of all, migration was a part of a family strategy for ensuring the standard of living of their families by providing health care and educational support to their members along with fulfilling other daily needs. This often became necessary when the breadwinner of the family became ill or died. It was well explained by an employee of the Bangladesh Central Bank whose four brothers live in Padova:

My father was a government employee, but when he became ill, our family fell into a deep economic crisis [...] my father was having problems bearing the cost of education for our eight siblings [four brothers and four sisters] along with our family expenditures. Thus, my father sent my elder brother first to Italy, after that my three other brothers migrated year after year to Italy in order to help the others, and later their families also joined them. (Interview 15, 11. 3. 2013)

However, many interviewees in Padova and Cadoneghe and their non-migrant family members in Bangladesh stressed that, just as with Della Puppa's (2013) findings in Alte Ceccato in the Province of Vicenza, global inequality (Cohen 1987) put Bangladesh in a subordinate position relative to Europe. Migration to Italy, therefore, offered them the possibility of better employment with higher salaries compared to Bangladesh. For instance, speaking of his brother, who had worked in Padova and Cadoneghe for eight years, one non-migrant respondent in Bangladesh said:

[...] they have the opportunity to have better income compared to Bangladesh. Suppose I had been serving in the Bangladesh Police with the rank of Havildar, where my monthly salary would only be fifteen thousand Takas [approx. 150 Euros], after taking care of my family expenses I would not be able to save anything, I would even have problems paying for my children's education. That's why we send them to Italy, in order to have a better income and a better life [...] (Interview 14, 9. 3. 2013) 
Bangladeshi households use various migration strategies to achieve a more stable life and enhance their social status and prestige. A rice wholesaler in the Dhaka whose two sons live in Padova said: "It was my plan to send at least one of my sons to Europe so that he has a better life and European citizenship, which would also increase our family's status here in my country" (interview 16, 17. 3. 2013).

Several interviewees also brought up various negative factors that influenced their decision to migrate. As one respondent stated: "In Bangladesh, an honest man cannot live his life honestly and also there is a lack of security in life that influenced me to migrate" (interview 3, 3. 1. 2013). Another respondent said: "I could not tolerate many things in my country when I was in Bangladesh; it was not possible to express your opinion freely, the political situation is bad, and the human rights situation is absolutely in danger. Basically, these are the reasons why I migrated to Italy" (interview 4, 5. 1. 2013). As these two statements reveal, some of the respondents considered Europe as a safe destination, in contrast to Bangladesh where they experienced or witnessed insecurity, political vulnerability, and a poor human rights situation.

Our interview findings show that migration decisions were also influenced by the migrants' social networks (Boyd 1989; Ambrosini 2006; Ryan et al. 2008). Such social relationships and contacts were also vital in the case of the migration decisions made by the Bangladeshi migrants in Padova and Cadoneghe. It was common that when one of the family members or relatives migrated to Italy, he helped other members to move there. As one of the respondents stated: "My older brother first came here to Padova in 1994 and I came here four years later" (interview 11, 26. 1. 2013). Another respondent said: "One of my mother's brothers lived in Italy. My family asked my uncle and he arranged my visa. Then I came to Italy in 2000" (interview 12, 2. 2. 2013).

Semi-structured interviews with irregular Bangledeshi migrants revealed another interesting issue. They often provided important information about their current situation in the destination country, served as info-points for various travel, employment and integration information and sometimes helped to finance the migration for potential migrants. (Ambrosini 2006). In this regard, some of them emphasised that they chose Italy, specifically Padova, because they were motivated by the information that irregular migrants can easily access the labour market in this Italian province. For instance, one respondent who arrived in Padova in 1990 said: "I chose to come here to Padova because my brother told me that I could earn money principally and honestly by selling flowers in the street. This is not allowed in all cities in Italy. I think that is the reason why most of the Bangladeshis used to come to Padova" (interview 11, 26. 1. 2013).

\section{REGION OF ORIGIN}

Bangladeshi respondents in Padova and Cadoneghe come from different Bangladeshi provinces and according to the research are much more heterogeneous than 
Figure 1: Regional origin of Bangladeshi Migrants in Padova by district

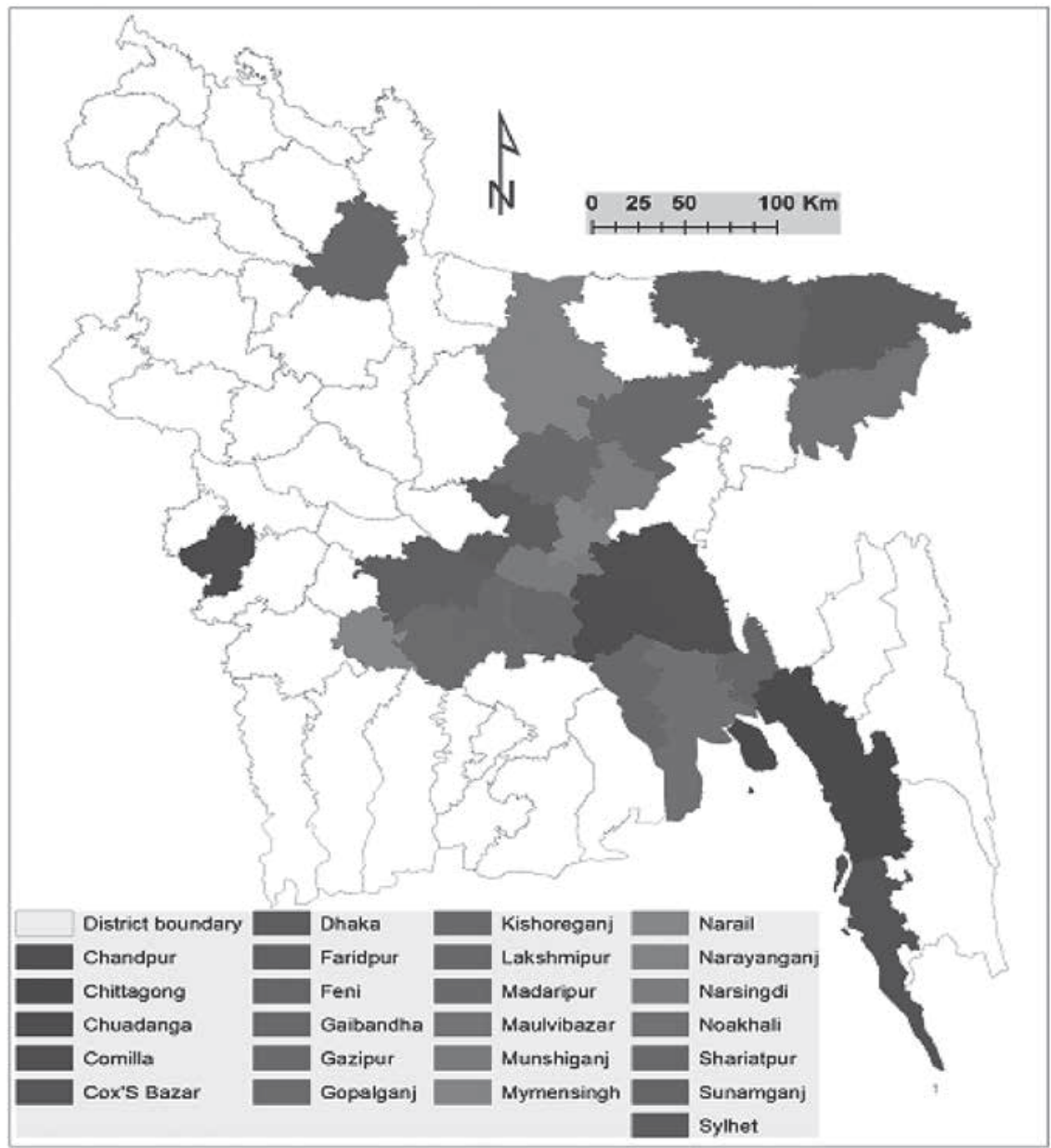

Source: Authors' field survey 2012-2013

those from some other destinations. ${ }^{5}$ They originate from five divisions (out of seven). In terms of distribution by district [Figure 1], the respondents migrated from 24 districts in Bangladesh. The districts represented most strongly in Padova and Cadoneghe are Comilla, Sylhet, Dhaka, Shariatpur, Madaripur and Narayanganj. They also originate from 46 upazilas. As it has already been mentioned, the three Bangladeshi migrants who arrived first in Padova and Cadoneghe came from three upazilas

5 We analyzed the regional origin of Bangladeshi migrants in Padova, Italy on the basis of three different administrative levels - Division, District, and Upazila. Bangladesh is divided into seven divisions (Barisal, Chittagong, Dhaka, Khulna, Rajshahi, Rangpur, and Sylhet) that are the country's major administrative regions. The divisional headquarters are located in the major cities of the country. The divisions are further divided into 64 districts and these districts again subdivided into 493 upazilas, i.e. sub-districts (BBS 2011). 
- Kanaighat in the Sylhet district, Debidwar in Comilla, and Naira in the Shariatpur district. So it comes as no surprise that the majority of our respondents originate from these three local administrative centres due to their widespread and effective migration networks.

In general, this regional origin indicates the gradual development of international migration from several other corners of Bangladesh rather than just from Sylhet, the district from which most of the migration to the UK took place (Garbin 2008; Gardner 1995, 2010) or the Noakhali and Chittagong regions, from where most Bangladeshi migrants in the Middle East originate (Knights 1996b).

It has already been well reported that in the case of the first generation of Bangladeshi migrants in the UK, the majority of them had rural agricultural backgrounds and originated from the Sylhet region (Zeitlyn 2006). Similarly, our research indicates that majority of the respondents in Padova and Cadoneghe also migrated from rural areas and have an agricultural background. For instance, among the 100 participants in our survey, only 20 originated from urban areas, mostly from the Dhaka district.

\section{CULTURAL, SOCIO-DEMOGRAPHIC AND ECONOMIC PROFILES OF BANGLADESHI MIGRANTS IN PADOVA AND CADONEGHE}

\section{Cultural and socio-demographic profiles}

Most of our Bangladeshi respondents (97 out of 100) were Muslims, and the others were Hindus. All of them are involved in religious and cultural activities in mosques and various cultural associations.

Also, official sources show that Bangladeshi migrants in Italy are mostly male (72 percent male, 28 percent female) (Istat 2016). The same source also indicates that in 2015, over 63 percent (1,051 individuals) of the 1,661 Bangladeshi residents in the Province of Padova and Cadoneghe were male. The majority of the respondents in our survey were male (89 respondents) and married (83 respondents). Only one third (30 out of 100) stated that their partners lived with them in Padova and Cadoneghe. The interview findings show that female migrants in Padova and Cadoneghe mostly joined their husbands on family reunification visas from the late 1990s on. However, most of the interviewees considered the family visa procedures to be complicated, lengthy and costly.

Over 50 percent of the respondents in Padova and Cadoneghe were young, most of them between the ages of 18 and 35 . Only eight percent of the respondents were over 50 years old. The average age was 35, the youngest being 20 and the oldest 58 .

As some of the studies indicate, many of the first-generation migrants from Bangladesh to the UK were mostly illiterate, and those who migrated later also had no or lower levels of formal education (Gardner 1995). In the case of migration to the 
Middle East, Osmani (1986) reveals that 83 percent of Bangladeshi migrants had not finished secondary school, while only 7 percent of Bangladeshi workers in Singapore had university degrees (Rahman 2010). By contrast, our findings show that 25 of our respondents had graduated or held postgraduate degrees even before migrating to Italy. 54 percent of them had secondary-level education (college or high school certificates). Also, most of the Bangladeshi community leaders in Padova and Cadoneghe have backgrounds in higher education. For example, among the 12 community leaders that we interviewed, seven had bachelor's degrees and two had Master's degrees.

\section{Economic profile}

Different studies show that most of the Bangladeshi migrants who came to Italy in the 1990s belonged to the upper middle class. They mostly came from families of landowners, entrepreneurs, lawyers, teachers, civil servants, military officers, and managers (Della Puppa 2013). However, they still mostly found work as unskilled labourers (ibid.). Our findings indicate that Bangladeshi migrants in Padova and Cadoneghe participate in the Italian economy in three ways: as employees, as street hawkers, and as entrepreneurs.

Most of our respondents were employed as factory workers (49 out of 100), ten of them were restaurant waiters and four sold fruit and vegetables at market stalls. Street hawkers ( 8 of the respondents) are also a prominent feature in Padova and Cadoneghe. They sell flowers, toys, jewellery, souvenirs, handbags, umbrellas and tourism materials on the streets. These street merchants are mostly undocumented, which indicates that it is possible for irregular migrants in Italy to work without the required documents (Reyneri 2001). One of the interviewed Bangladeshi community leaders pointed this out:

I would say 60 percent of these street hawkers are undocumented. Most of them arrive legally as seasonal workers for 8 to 9 months. But when their contract period ends, they usually do not go back to Bangladesh. They are illegal, they have no way to officially hold any job, so they start selling flowers, umbrellas, toys etc. on the street, where they can earn their livelihood. (Interview 11, 26. 1. 2013)

On the other hand, 11 of the respondents were entrepreneurs. Many of them are owners of clothing, vegetable and fruit shops. Bangladeshi-owned clothing shops are mostly located in the Piazza dei Signoi and vegetable and fruit shops are located in the Piazza Cavour in the city centre. A number of the respondents also run pizza and kebab shops. Some of the respondents also opened Bangla food shops. Bangladeshi spices, vegetables, fish, fruits, sweets, snacks, halal meat and some other necessary ethnic food items are readily available in these shops. This is a relatively new development as these "ethnic" goods were not available before 2000 as one of the respondents noted: 
The most important thing I would like to say is that when I first arrived in Padova, there were no Bangla shops. In Vicenza and Mestre, there were some Bangla shops. We had to get some other Bangla food in Rome. For instance, all leafy vegetables and green chilis were only available in Rome [...] But now this has changed; there are 7 Bangla grocery shops in this city and you can find all of the items that you need. (Interview 12, 2. 2. 2013)

Some of the Bangladeshis also started small gardens and farms and were cultivating various Bangladeshi leafy vegetables such as Pui Shak (Indian spinach), Mula Shak (Radish leaf), Lal Shak (Red Spinach), Palong Shak (Spinach), Pat shak (Jute leaves) and also non-leafy vegetables such as Dherosh (Ladyfinger), Misti Kumra (Sweet Gourd), Lau (Bottle Gourd), Chichinga (Snake Gourd) and so on.

Our research shows that the group with highest income are the entrepreneurs, especially those who run clothing businesses, pizza and kebab shops and Bangla food shops. The majority of them make roughly 3000-4000 Euros per month and some even more. The second important income group are the factory workers, the majority of them earning between 1500 and 2500 and some of them 2000-2500 Euros per month. Street hawkers earn between 500 to 1000 and other employees - waiters, market stall assistants - around 1000-1500 Euros per month. All of the female respondents in the survey (10 out of 100) have no income as they are mostly dependent on their partners. Overall, the study showed that the average monthly income of our respondents was around 1300 Euros.

The results of the analysis also clearly indicate that the respondents' education level has little or no bearing on their current occupation or activities. Those with higher education are mainly found in the blue collar sector, working in factories, restaurants, supermarkets and as farmers. Those with university degrees in most cases earn as much as those with secondary level education. Similarly to Zeitlyn's (2006) study of Bangladeshi migrants in Madrid, some of the interviewees pointed out that they have the feeling of 'stepping down' in their occupations and activities compared to their situation in Bangladesh. They stated that they "were running their own business in their country of origin, but they are working now for someone else as manual labourers".

The qualitative interviews suggest that some of the earlier migrants to Padova were very successful in setting up businesses or finding relatively permanent jobs in the factories. However, now most of the workers in the factories, shops, stalls and restaurants are in a more precarious position. As the number of migrants is growing day by day it is very difficult for newcomers to establish themselves and find a good and stable job in order to be able to fulfil their migration aspirations. Street vending, which was traditionally considered one of the possible survival strategies by Bangladeshi migrants, has also become very competitive due to the growing number of newcomers and unemployed.

Our interviews also suggest that many of the respondents with permanent residence permits are considering migrating to other EU countries after obtaining their 
citizenship, while some citizens have decided to leave towards several new destinations, mainly to the UK. However, it seems that since the Brexit referendum some of them are in a hurry and others are considering changing their migration strategy.

\section{CONCLUSION}

Probashi in Italy are not only targeting big cities like Rome and Milan as their possible migration destinations, as their strong presence has also been observed in several smaller cities and towns throughout Italy. The research has shown that the Bangla community in Padova and Cadoneghe was formed by a few Bangladeshis who first arrived in Rome and later moved to the Province of Veneto during the late 1980s. In 30 years, they have become one of the largest non-European migrant communities in this region. By using regular and irregular channels and with the help of migration networks, they managed to cross Italian border from different European and Middle Eastern countries and Bangladesh.

Our empirical evidence suggests that whereas Bangladeshi migration to the Middle East and Asia is mostly linked to unemployment and poverty (Zeitlin 2007), the motivation for migration to Italy is mainly aimed at ensuring a higher standard of living for migrants and their families, the possibility of having better paid employment or a more successful business, upward social mobility, as well as upgrading social status and prestige along with a more stable life situation. Their migration decision is also heavily influenced by their social networks with their family members and relatives that already live in Italy.

Our findings related to the geographic distribution of migrants in Bangladesh shows the gradual development of migration trajectories from this country to Italy. Migrants who live in Padova and Cadoneghe originate from several parts of Bangladesh, and different divisions, districts and upazilas. A significant number of them are well-educated, as they hold degrees from secondary schools and universities. However, education clearly has little or no influence on their occupation and wages, as most of them have a feeling of 'stepping down' with respect to their previous positions in their country of origin. Even though it is evident that some migrants are successful, others still feel that they have yet to fulfil their migration aspirations. This study further indicates that most of the respondents have plans for further movement towards a new destination; especially those who have obtained Italian citizenship or are long-term residence permit holders. Most of them aspire to go to the UK, but after the Brexit referendum they are reconsidering their decisions and directions. In this regard, further research should be carried out to explore their onward migration plans. 


\section{REFERENCES}

Ambrosini, Maurizio (2006). Delle reti e oltre: Processi migratori, legami sociali e istituzioni. Stranieri in Italia: Reti migrant (a cura di Francesca Decimo, Giuseppe Sciortino). Bologna: II Mulino, 21-58.

Boyd, Monica (1989). Family and Personal Networks in International Migration: Recent Developments and new Agendas. International migration review 23/3, 638-670.

BMET (2016). Employment of Bangladeshi Workers from 1976 to 2016. Bureau of Manpower, Employment and Training, Government of the People's Republic of Bangladesh, http://www.bmet.gov.bd/BMET/stattisticalDataAction\# (28. 12. 2016). Cohen, Robin (1987). The New Helots: Migrants in the International Division of Labour. Aldershot: Avebury.

Della Puppa, Francesco (2013). A Bidesh1 in the Middle of the Mediterranean Sea: Biographical Trajectories and Migration Patterns in the Bangladeshi Diaspora in Italy2. ARS \& HUMANITAS 7, 99.

Della Puppa, Francesco (2014). Uomini in movimento: Il lavoro della maschilità tra Bangladesh e Italia. Torino: Rosenber \& Selier.

Della Puppa, Francesco (2015). Home Between bidesh and shodesh: Domestication of Living Spaces, Identity and Gender Experiences in the Bangladeshi Diaspora. Dve Domovini / Two Homelands 42/2, 97-111.

Della Puppa, Francesco, Gelati, Enrico (2015). Alte Ceccato: Una banglatown nel nordest. Trento: Professionaldreamers.

Delicato, Vincenzo (2004). National Legislation and good Practices in the Fight against Illegal Migration-the Italian Model. Rim: CARDS Programme.

Garbin, David (2008). A Diasporic Sense of Place: Dynamics of Spatialisation and Transnational Political Fields among Bangladeshi Muslims in Britain. Transnational Ties: Cities, Identities and Migration (eds. Michael Peter Smith, John Eade). New Brunswick, London: Transaction Publishers, 147-161.

Gardner, Katy (1995). Global Migrants, Local Lives: Travel and Transformation in Rural Bangladesh. Oxford: Oxford University Press.

Gardner, Katy (2010). Transnazionalismo e trasformazioni dall' "estero" dell'idea di "casa" nel Sylhet, Bangladesh. Mondi migrant 3: 7-22.

ILO (2014). Skilling the Workforce: Labour Migration and Skills Recognition and Certification in Bangladesh. Dhaka: International Labour Organization (ILO), Country Office for Bangladesh.

ISTAT (Istituto Nazionale di Statistica) (2016a). Foreign Citizens. Resident Population by Sex and Demographic Balance on 31st december 2016, http://demo.istat.it/str2016/index_e.html (17. 3. 2017).

ISTAT (Istituto Nazionale di Statistica) (2016b). Demographic Balance for the year 2016, Italy, http://demo.istat.it/bilmens2016gen/index_e.html (17. 3. 2017). 
King, Russel, Rybaczuk, Krysha (1993). Southern Europe and the International Division of Labour: From Mass Emigration to Mass Immigration. The New Geography of European Migrations (ed. Russel King). London: Belhaven, 175-206.

Knights, Melanie (1996 a). Bangladeshis in Rome: The Political, Economic and Social Structure of a Recent Immigrant Group. Questioni di Popolazione in Europe: Una prospettiva geografica (eds. Maria Luisa Gentileschi, Russel King), 129-142.

Knights, Melanie (1996b). Bangladeshi Immigrants in Italy: From Geopolitics to Micropolitics. Transactions of the Institute of British Geographers, 105-123.

Knights, Melanie, King, Russel. (1998). The Geography of Bangladeshi Migration to Rome. International Journal of Population Geography 4/4, 299-321.

Luongo, Patrizia (2011). Case Study: The Veneto Region: A Study Report by European Union in the Framework of Europ'Act.

Morad, Mohammad, Gombač, Jure (2015). Transmigrants, Transnational Linkages and Ways of Belonging: The Case of Bangladeshi Migrants in Italy. Dve Domovini / Two Homelands 41/1, 61-76.

Morad, Mohammad, Haque, Shahabul, Alam, Jahangir (2014). Contextualizing Formation of Diaspora of Bangladeshi Immigrants in the UK. Research in Social Change 6/2, 103-128.

Osmani, Siddiqur Rahman (1986). Bangladesh. Migration of Asian workers to the Arab world (ed. Godfrey Gunatilleke). Tokyo: United Nations University Press, 23-65.

Priori, Andrea (2012). Romer probashira. Reti sociali e itinerari transnazionali bangladesi a Roma. Rim: Meti.

Quattrocchi, Patrizia, Toffoletti, Mikol, Tommasin, Elena Vera (2003). Il fenomeno migratorio nel comune di Monfalcone: Il caso della comunità Bengalese: Rapporto di ricerca. Gradišče ob Soči: A.R.E.A.S.

Rahman, Md Mizanur (2010). Remittances as a Docial Process: The Singapore-Bangladesh Remittance Corridor. Asian and Pacific Migration Journal 19/2, 265-294.

Rahman, Md Mizanur (2012). Bangladeshi Labour Migration to the Gulf States: Patterns of Recruitment and Processes. Canadian Journal of Development Studies $33 / 2,214-230$.

Rahman, Md Mizanur, Kabir (2012). Bangladeshi Migration to Italy: The Family perspective. Asia Europe Journal 10/4, 251-265.

Ryan, Louise, Sales, Rosemary, Tilki, Mary, Siara, Bernadette (2008). Social Networks, Social Support and Social Capital: The Experiences of Recent Polish Migrants in London. Sociology 42/4, 672-690.

Reyneri, Emilio (2001). Migrants' Involvement in Irregular Employment in the Mediterranean Countries of the European Union, ILO International Migration Papers No. 41.

Siddiqui, Tasneem (2003). Institutionalising Re-bonding: Bangladeshi Diaspora in UK and US. Dhaka: Ministry of Expatriate Welfare and Overseas Employment of GoB and IOM [mimeo].

Siddiqui, Tasneem (2004). Institutionalizing Diaspora Linkage: The Emigrant Bangladeshi in UK and USA. Dhaka: GoB, IOM. 
Zeitlyn, Benjamin (2006). Migration from Bangladesh to Italy and Spain (No. 11). Refugee and Migratory Movements Research Unit.

Zeitlyn, Benjamin (2007). Senders Turned into Receivers: Spain, Italy and Bangladeshi Migration. Paper presented ad Eight Mediterranean Social and Political Research Meeting, Firence.

\section{POVZETEK}

\section{»PROBASHIJI« V ITALIJI. NOVE DESTINACIJE: TRENDI, IZVORI IN PROFILI BANGLADEŠKIH MIGRANTOV V PADOVI IN CADONEGHEJU Mohammad MORAD, Jure GOMBAČ}

Avtorja v članku ugotavljata, da se večina znanih do sedaj objavljenih raziskav o migracijah iz Bangladeša v Italijo osredotoča na mesta z dolgoletnimi izkušnjami z bangladeškimi skupnostmi, kot so na primer Rim, Vicenza in Benetke. Vendar pa za t. i. "probašije«, bangladeške migrante, ki se priseljujejo v Italijo, kot zanimiva destinacija vedno pomembnejša postajajo tudi manjša mesta in občine, kjer iščejo možnosti in priložnosti za delo in življenje. Ker je bilo v zadnjem času na zemljevid italijanskega polotoka, zlasti na industrijsko bolj razvitem severu, dodanih kar nekaj novih t. i. »Bangla-mest", se v svojem članku osredotočata na mesti Padova in Cadoneghe v Benečiji. Raziskave sta se lotila s pomočjo anketnih vprašalnikov in številnih intervjujev $z$ bangladeškimi migranti ter s pridobljenimi podatki sestavila zanimivo sliko bangladeških skupnosti v obeh mestih. Zanimalo ju je, kakšni so trendi, kanali in motivacije za selitev v Padovo in Cadoneghe, iz katerih bangladeških regij in krajev ti migranti prihajajo in kakšno je njihovo kulturno, družbeno in ekonomsko ozadje.

Odgovori na v raziskavi postavljena vprašanja o tej aktualni temi, ki je v zadnjih letih pomembno zaznamovala politiko te transnacionalne skupnosti, dajejo zanimivo podobo današnjih migracij v Evropsko unijo. Analiza podatkov namreč kaže, da naslavljajo številne migracijske teme in rušijo stereotipe o nevarnih, lenih, neizobraženih migrantih, ki ogrožajo naše meje, kulture in države blaginje. 